\title{
IMPLEMENTASI JUAL BELI LELANG PERSPEKTIF ISTISHAB
}

\author{
Siti Mahmudah \\ Universitas Islam Negeri Sunan Ampel Surabaya \\ e-mail: mudahsiti95@gmail.com
}

\begin{abstract}
This article aims to examine the sale and purchase of auctions from the perspective of istishab. Buying and selling auctions have occurred in the community and develop according to needs. However, the law regulating auction buying and selling is still a metter of debate among the public. The subject of this article is buying and selling auctions. Research method library research eith a descriptive approach. The propet Muhammad SAW to buy and sell auctions, as the practice applied by the propet Muhammad was to assist his friends in auctioning aff his slaves and the proceeds from the auctions of slaves were intended for his treatment.then the law of buying and selling auctions is permitted until there is a legal basis that can chage the law. The purpose of holding a sele and purchase auction is to assist and assist parties experiencing financial problems. Istishab, namely enforcing exixting law until a ne law is found for an event. Buying and selling auctions is allowed by islam because it does not harm others. The practice of buying and selling auctions is carried out in public and withnessed by everyone and there is not manipulation by certain partiens.
\end{abstract}

Keywords: Istishab, buying and selling auction, buying and selling of auctions during the time of the Nabi Muhammad

\section{A. PENDAHULUAN}

Islam memiliki pedoman yang dijadikan sebagai panduan dalam kehidupan. Panduan tersebut ialah hukum Islam yang dapat dijadikan sebagai solusi menyelesaikan masalah. Hukum Islam merupakan suatu aturan Islam yang mengatur segala hukum yang dibutuhkan seluruh manusia. Pembagian hukum Islam dapat dibagi menjadi beberapa macam yakni sumber hukum yang disepakati meliputi al-Qur'an, hadis, ijma' dan qiyas dan sumber hukum yang masih diperdebatkan kehujjahannya meliputi istihsan, istishab, 'urf, yar'u man qablana, sad al-zari' ah, madhab sahaby. ${ }^{1}$

Berbagai macam transaksi jual beli telah dilakukan oleh berbagai kalangan masyarakat. Transaksi tersebut didasarkan atas dasar kerelaan setiap orang yang terlibat. Begitu pula jual beli memiliki beragam macam

\footnotetext{
1 Ridwan, "Istishab dan penerapannya dalam hukum Islam", al-manahij, Vol.v No. 1 Januari 2011, 1.
} 
mulai dari jual beli tatap muka atau saling bertemu sampai dengan sistem pemesanan yakni salam dan istisna'. Salah satu transaksi jual beli yang jarang dilakukan oleh masyarakat tetapi menghasilkan untung yang besar ialah jual beli lelang karena jual beli ini memilki ketentuan dan syarat tertentu. Ketentuan tersebut berlaku karena barang yang diperjual belikan memilki nilai atau nominal yang lebih besar. Misalnya lelang rumah, perusahaan dan lain sebagainya.

Tujuan artikel ini ialah untuk menjelaskan dan memaparkan mengenai jual beli lelang menurut konsep istishab. Istishab merupakan sumber hukum yang tetap diterapkan pada setiap kejadian meskipun telah terjadi pergantian zaman maupun kondisi. Dasar hukum tersebut akan tetap bertahan dan dapat digunakan selama sumber tersebut tidak bertentangan dengan sumber utama yang telah ada. Bersumber dari uraian yang telah dipaparkan, maka pada artikel ini akan membahas mengenai jual beli lelang dalam perspertif istishab.

\section{B. METODE PENELITIAN}

Kajian ini merupakan studi kepustakaan (library research). Library research merupakan sekumpulan kegiatan mengenai metode pengumpulan data pustaka, membaca, mencatat dan mengolah data menjadi bahan penelitian. Library research ialah kegiatan untuk memaksimalkan data yang bersumber dari studi kepustakaan. ${ }^{2}$ Pada penelitian ini, penulis menggunakan penelitian deskriptif dengan menekankan pada kekuatan analisis yang berdasarkan sumber dan data yang telah ada.

Sumber data pada penelitian ini yakni berupa personal document sebagai sumber dasar atau data primernya. Data tersebut terdiri dari buku-buku, jurnal, ensiklopedi, majalah, makalah, artikel dan lain-lain yang relevan. Sumber data tersebut berkaitan dengan konsepsi produk dan akad syariah mengenai transaksi bermuamalah.

Teknik library research adalah "penelitian kepustakaan yang dilaksanakan dengan cara membaca, menelaah dan mencatat berbagai literatur atau bahan bacaan sesuai dengan pokok bahasan, kemudian disaring dan dituangkan dalam kerangka pemikiran secara teoritis". 3 Teknik pengumpulan ini dilakukan untuk memperkuat fakta dan membandingkan perbedaan antara teori dan praktek.

Metode analisis yang digunakan pada penelitian ini ialah pendekatan deskriptif. Pendekatan deskriptif yakni usaha untuk mengumpulkan dan menyusun data, selanjutnya dilakukan analisis terhadap data

\footnotetext{
${ }^{2}$ Mustika Zed, Metode Penelitian Kepustakaan (Jakarta: Yayasan Obor Nasional, 2004), hlm. 2-3

${ }^{3}$ Kartini Kartono, Pengantar Metodologi Research, ( Bandung: ALUMNI, 1998), hlm. 78
} 
tersebut dan ditarik kesimpulan. ${ }^{4}$ Pandangan analisis data deskriptif tersebut merupakan data yang dikumpulkan berupa kata dan gambar bukan dalam bentuk angka, hal tersebut dikarenakan adanya penerapan metode kualitatif. $^{5}$ Dengan demikian, laporan penelitian akan berisi kutipan data untuk memberikan gambaran penyajian mengenai hasil laporan.

\section{HASIL DAN PEMBAHASAN Konsep Istishab}

Istishab berawal dari kata is-tash-ha-ba (استصحب). Secara lughawi memiliki makna yaitu usaha untuk mendekatkan satu peristiwa hukum dengan peristiwa lainnyan supaya kedua penjelasan tersebut memiliki hukum yang sama. Hasby ashShiddiqy menjelaskan tentang istishab ialah,

البقاء ما كان على ما كان عليه .لعدام

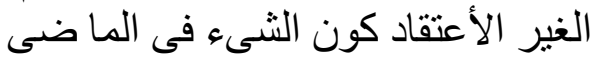

او الحا ضر يوجب ظن ثبو ته في الحال<smiles>[AlH2]</smiles>

"mengekalkan sesuatu berdasarkan keadaan yang telah ada, karena tidak ada hukum yang mengubahnya atau karena uatu hal yang belum diyakini."'6

\footnotetext{
${ }^{4}$ Winarno Surachman, Pengantar

Penelitian Ilmiah: Dasar, Metode, Teknik (Bandung: Tarsita, 1990), Hal. 139

5 7Lexy J. Moleong. Metodologi Penelitian Kualitatif, (Bandung: PT. Remaja

Rosdakarya, 2002), Hal. 162

${ }^{6}$ Al-Asnawy, Abd al-Rahim ibn Hasan alSyafie i, t.t., Nihayah al-Saul fi Syarh
}

Al-Syaukani dalam kitab Irsyadul Fuhul ila tahqiqil haq min ilmil ushul menjelaskan istishab yakni

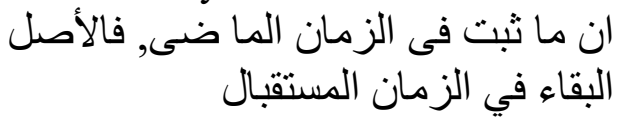

"Apa yang pernah berlaku secara tetap pada masa lalu pada prinsipnya tetap berlaku pada masa yang akan datang". 7

$$
\text { Imam al-Asnawy }
$$

mengartikan Istishab sebagai berikut,

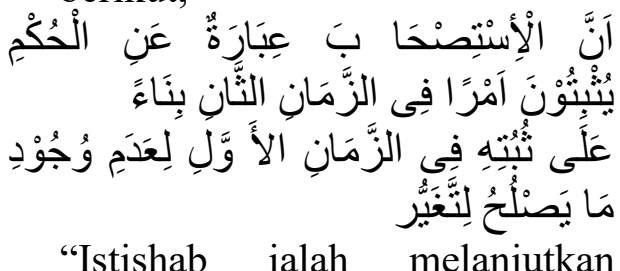
hukum yang sudah berlaku dan telah ditetapkan ketetapan hukumnya terhadap suatu dalil sampai ditemukannya dalil lain yang mengubah ketentuan hukum tersebut." 8

$$
\text { Para pakar Ushul }
$$

mengartikan istishab yaitu menentukan hukum pada suatu peristiwa sesuai dengan keadaan sebelumnya sampai pendapat atau dasar hukum yang menyatakan perubahan keadaan tersebut. Al-istishab menurut alGhazali adalah ketentuan hukum tidak menurut kepada ketidaktahuan mengenai dalil

Minhaj al-Ushul, (Kairo: Al-Mathba ${ }^{e e}$ ah alSalafiyah), Hal. 178.

\footnotetext{
${ }^{7}$ Al -Syaukany, Muhammad ibn Ali, Irsyad al-Fuhul ila Tahqiq al-Haq min 'Ilm al-Ushul, (Beirut :Dar al-Kutub al'Ilmiyyah). Hal. 267.
}

${ }^{8}$ Ibid., 365. 
tetapi berdasarkan kepada argumentasi dalil akal maupun syara' yang dilakukan melalui pembahasan, diskusi dan sesuai dengan dalil yang ada. ${ }^{9}$

Ibn Qayyim mengartikan istishab ialah pernyataan yang tetap menggunakan hukum yang telah ada terhadap suatu peristiwa yang terjadi. $^{10}$ Sedangkan menurut al-Syatibi ialah segala ketetapan hukum yang berlaku pada masa lampu dan tetap berlaku pada masa sekarang. ${ }^{11} \quad$ Berdasarkan berbagai pendapat yang dipaparkan tersebut pemakalah memilih pendapat al-Asnawy yang menjelaskan bahwa segala hukum yang berlaku pada masa lampau tetap berlaku pada masa sekarang. Pendapat tersebut mengarah kepada suatu hukum tidak dapat berubah sampai ada dalil yang merubahnya.

Secara etimologi istishab memiliki arti meminta kebersamaan (thalab almushahabah) atau kebersamaan yang berlanjut (istismrar ashshuhbah). Sedangkan menurut istilah memiliki makna ketetapan hukum yang diterapkan pada saat ini sesuai dengan keadaan sebelumnya sebelum ada dalil baru yang merubahnya. ${ }^{12}$

\footnotetext{
${ }^{9}$ Darmawan, Ushul Fiqh, (tt: revka prima media anggata IKAPI, 2020), 196.

${ }^{10}$ Ibid, 197.

${ }^{11}$ Siti Shalihah, "istishab (sebuah teori dan praktik prinsipprinsip nahwu arab)”, alittijah, Vol. 10 No. 02 (Juli-Desember 2018) al -ittijah, 55.

12 Darmawan, Ushul Fiqh, (tt: revka prima media anggata IKAPI, 2020), 199.
}

\begin{abstract}
Berdasarkan uraian tersebut dapat disimpulkan bahwa konsep istishab mengandung tiga unsur pokok yakni segi waktu, ketetapan hukum dan dalil hukum. Istishab dibagi dalam dua bentuk yakni Tsubut (keadaan telah ada suatu hukum) dan Nafi (keadaan belum pernah ada hukumnya). Contohnya pertama apabila seseorang ketika pagi hari telah berwudhu untuk shalat subuh, maka orang yang memilki wudhu tersebut tetap bisa menunaikan shalat dhuha sampai terdapat bukti yang menejelaskan bahwa wudhu yang dimilki orang tersebut telah batal. Kedua penetapan kepemilikan harta dapat melalui pewarisan mapun hibah secara sah. Kepemilikan berlaku secara terus menerus sampai ditemukannya bukti peralihan harta. ${ }^{13}$
\end{abstract}

\section{Unsur-unsur istishab}

Istishab memilki tiga unsur pokok yakni ketetapan hukum, dalil hukum dan waktu. Amir Syarifuddin membagi istishab menjadi beberapa kriteria yani:

1. Keteguhan.

Suatu keadaan yang disebabkan oleh keadaan masa lalu berdasarkan kepada hukum syara' atau obyek hukum syara'. Contohnya keyakinan terhadap kepemilikan harta bagi

${ }^{13}$ Husnul Haq, "Penggunaan Istishab dan pengaruhnya terhadap perbedaan ulama", ALHURRIYAH : Jurnal Hukum Islam, Vol. 02 , No. 01., Januari-Juni 2017, 19. 
seorang ahli waris karena pewarisan dari orang tua.

2. Keraguan.

Keraguan masih

berlakunya sesuatu karena waktunya telah berubah. Misalnya tentang waris, seseorang merasa ragu terhadap harta yang diwariskan keadaannya karena ditakutkan harta warisan tersebut telah dialihkan kepada orang lain.

3. Sesuatu yang meyakinkan dan meragukan pada saat bersamaan.

Terjadinya keraguan dan keyakinan pada masa sekarang dan bertemu sekaligus karena belum ada pendapat yang menjelaskan mengenai perubahan dasar hukum sehingga suatu kejadian yang terjadi dapat menggunakan dasar hukum yang lama. Misalnya memiki keyakinan melakukan wudhu untuk sholat subuh tetapi memilki keraguan untuk melakukan sholat dhuha dengan wudhu yang sama.

4. Kondisi keyakinan dan keraguan dalam waktu yang berbeda.

Keyakinan seseorang terjadi pada masa lampau dan kondisi yang meragukan terjadi pada masa sekarang. Misalnya ijab qabul jual beli pada masa lalu harus diucapkan secara jelas oleh penjual dan pembeli tetapi masa sekarag penjual dan pembeli hanya menyerahkan uang kepada penjual bahkan dapat dilakukan melalui aplikasi smartphone. ${ }^{14}$

\section{Syarat Istishab}

1. Pemakai istishab harus memilki kemampuan untuk menemukan bukti yang dapat merubah hukum lama. Pada tahapan ini pengguna istishab harus bekerja keras dalam melakukan perubahan tetapi tetap berdasarkan kepada hukum syara' maupun nash al-Qur'an.

2. Hukum asal berasal dari dalil syara' maupun yang berasal dari akal tetapi bukan semacam dugaan. Penentuan hukum ini melalui metode istishab bukan berdasarkan perasaan tetapi berdasarkan kepada kemaslahatan umat.

3. Hukum asal bersifat mutlaq yakni dalil lama tidak menjelaskan keberlakuannya secara berkesinambungan dan tidak pula menjelaskan batas waktu tertentu. Hukum lama tersebut dapat dipergunakan seiring dengan perkembangan zaman tetapi tetap tidak bertentangan dengan hukum Islam.

4. Istishab dan nash tidak bertentangan. Apabila perselisihan terjadi antara keduanya, maka didahulukan yang lebih utama yakni nash al-Qur'an karena memiliki kekuatan hukum yang lebih tinggi dan merupakan sumber hukum yang utama ${ }^{15}$.

\section{Macam-macam Istishab}

\footnotetext{
${ }^{14}$ Ibid., 20.

15 Ibid., 22.
} 
Istishab terdiri dari beberapa macam yakni,

1. Al-Istishab hukm al-ibahah al-ashliyyah (berlakunya hukum mubah yang menjadi dasar)

yakni istishab yang didasarkan pada hukum asal dari sesuatu yang mubah. Dalam bidang muamalah penerapan istishab menimbulkan kesimpulan bahwa setiap transaksi muamalah hukumnya boleh sampai ada dalil yang menyatakan tidak boleh. Firman Allah dalam surat almaidah (5):87

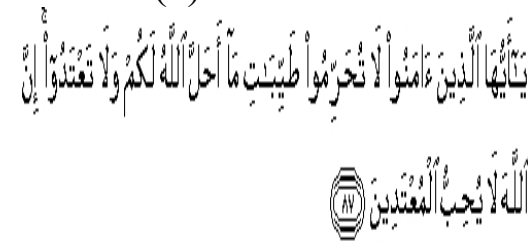

"Hai orang-orang yang beriman, janganlah kamu haramkan apa-apa yang baik yang telah Allah halalkan bagi kamu, dan janganlah kamu melampaui batas. Sesungguhnya Allah tidak menyukai orang-orang yang melampaui batas". (Qs. almaidah: 87) $)^{16}$

2. Istishab madallah asysyar'aw al- 'aql 'ala wujudih (istishab berdasarkan kepada sesuatu menurut akad atau syara')

yakni penetapan hukum berdasarkan kepada prinsip dasar yakni setiap orang bebas dari tuntutan beban sampai ada bukti yang dapat

${ }^{16}$ Departemen Agama RI, Al-Qur'an dan Terjemahannya, (Surabaya: Mahkota, 1971), 111. merubahnya. Misalnya pada dasarnya setiap orang bebas dari semua tanggung jawab sampai terdapat bukti yang menjelaskan bahwa orang tersebut mempunyai hutang. Berdasarkan contoh tersebut menjelaskan bahwa istishab ini menjelaskan tentang berlakunya hukum baik ditinjau dari syara' maupun logika sampai terdapat alasan atau dalil yang merupah ketentuan hukum tersebut. ${ }^{17}$

3. Istishab al-umum ila an yarid at-takasyi (berlakunya hukum umum sampai ada yang mengkhususkannya)

ialah penetapan hukum yang telah berlaku pada masa lalu dan tetap berlaku pada masa sekarang sampai ada dalil lain yang merubahnya. Pada istishab ini berkaitan dengan waktu. Misalnya, kepemilikan seseorang terhadap sebidang tanah atau harta lainnya akan tetap menjadi miliknya sampai ada bukti perubahan status hak milik. Perubahan tersebut antara lain jual beli atau sewa menyewa.

4. Istishab al-khash bi al-wasf (tetapnya hukum khusus yang berkaitan dengan sifatnya) yakni istishab yang didasarkan kepada anggapan masih tetapnya sifat atau sampai ada bukti yang mengubahnya. Pada istishab ini para ulama berbeda pendapat. Ulama syafi'iyah dan Hanabilah secara mutlak

\footnotetext{
${ }^{17}$ Darmawan, Ushul Fiqh, (tt: revka prima media anggata IKAPI, 2020), 181.
} 
menerimanya sebagai dalil syara'. Sedangkan ulama Hanafiyyah dan Malikiyah berpendapat bahwa istishab tidak dapat dijadikan sebagai dasar hukum yang baru tetapi hanya dapat dijadikan sebagai penolak hukum yang baru. Misalnya seseorang dianggap masih hidup sampai orang tersebut dinyatakan telah wafat atau apabila seseorang merasa sakit perut ketika pertengahan sholat, maka orang tersebut tidak boleh membatalkan sholat sampai ada bukti batalnya sholat misalnya keluarnya bau atau suara. ${ }^{18}$

\section{Kehujjahan Istishab}

Ulama ushul fiqh mengatakan sesungguhnya istishab adalah akhir tempat beredarnya fatwa yakni mengetahui suatu hukum yang telah ditetapkan baginya selama tidak terdapat dalil yang mengubahnya. Seorang manusia yang hidup tetap dihukumi hidup dan pengelolaan atas hidupnya sampai terdapat bukti tentang kematiannya. Contoh lain yakni seseorang dinyatakan memilki kepemilikan terhadap sebuah rumah dengan bukti sertifikat dan dianggap tidak memilki kepemilikan bagunan tersebut apa bila bangunan tersebut telah dijual atau berpindah kepemilikan. ${ }^{19}$

18 Ridwan," istishab dan penerapannya dala hukum Islam", $A l$ - manahij, vol. v no. 1 januari 2011, 3.

19 Rahmad Syafe'I, Ilmu Ushul Fiqh,(Bandung: Pusaka Setia, 2007), 99.
Syaikh Abu Zahra menegaskan bahwa para ulama sepakat terdapat tiga bentuk istishab yakni Istishab al-ibahah al-asliyyah, Istishab baraah alasliyyah dan Istishab al-hukm dapat dijadikan sebagai landasan hukum. Sedangkan para ulama berbeda pendapat tentang istishab keempat Istishab alwasf.

Istishab al-wasf dikelompokkan menjadi dua pendapat yakni pertama ulama Malikiyah, Syafiiyah seperti alMuzani, al-Sairafi, Imam alHaramain, al-Ghazali dan Hanabilah menjelaskan bahwa istishab al-wasf dijadikan sebagai hujjah secara penuh baik yang menimbulkan hukum baru maupun mempertahankan hukum yang sudah ada. Misalnya seseorang yang telah hilang atau tidak diketahui keberadaannya, maka orang tersebut tetap dianggap masih hidup dan memilki hak seperti hak mewarisi harta.

Kedua, ulama Hanafiyah dan Malikiyah berpendapat mengenai Istishab al-wasf hanya dapat digunakan untuk mempertahankan hukum lama tetapi bukan untuk menimbulkan hukum baru. Misalnya apabila seseorang menghilang maka akan tetap berstatus sebagai suami terhadap istri dan harta yang menjadi miliknya. Apabila ahli warisnya meninggal dunia maka kadar pembagian harta tersebut harus ditangguhkan. Sedangkan hukum orang yang mafqud diputuskan oleh 
pengadilan bahwa orang tersebut dinyatakan sudah meninggal.

Menurut pandangan 'Abd al-Wahhab Khallaf penolakan ulama mengenai Istishab al-wasf hanya kepada asumsi-asumsi yang bersifat spekulatif bukan kepada fakta. Lembaga peradilan telah menerapkan metode istishab untuk pengambilan putusan terhadap suatu perkara. Contohnya para hakim memutuskan kepemilkian hak milik bangunan atau tanah berdasarkan bukti akta autentik yang telah disahkan oleh badan pertanahan.

Sebagian Ulama usuliyyah menerima istishab sebagai dalil hukum. Menetapkan istishab sebagai dalil terakhir apabila tidak ditemukan dalil lain yang menjelaskan hukumnya. Hal tersebut bersandarkan kepada fakta hukum yang sudah ada dan akan selalu bergerak dinamis sesuai dinamika masyarakat ${ }^{20}$

Mayoritas ulama ulama Syafi'I, Maliki dan Hambali berbeda pendapat mengenai nilai kehujjahan istishab. Untuk memperkuat pandangan yang mereka kemukakan, mereka menggunakan al-Qur'an, hadis, ijma' dan akal. Sebagaimana dalam surat al- an'am: 145,
20 Ridwan," istishab dan penerapannya dala hukum Islam", $A l$ - manahij, vol. v no. 1 januari 2011, 5 .

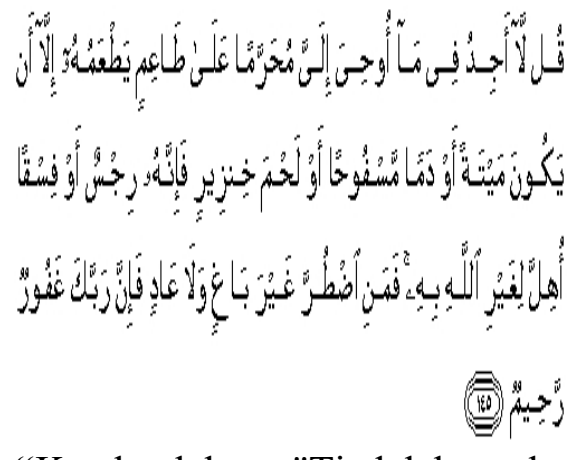

"Katakanlah: "Tiadalah aku peroleh dalam wahyu yang diwahyukan kepadaku, sesuatu yang diharamkan bagi orang yang hendak memakannya, kecuali kalau makanan itu bangkai, atau darah yang mengalir atau daging babi karena sesungguhnya semua itu kotor - atau binatang yang disembelih atas nama selain Allah. Barangsiapa yang dalam keadaan terpaksa, sedang dia tidak menginginkannya dan tidak (pula) melampaui batas, maka sesungguhnya Tuhanmu Maha Pengampun lagi Maha Penyayang (Qs alAn'am:145)"21

\section{Kaidah Istishab}

Beberapa kaidah yang terdapat dalam istishab antara lain,

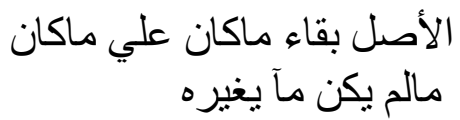

"Hukum asal itu tetap dalam keadaan tersebut selama tidak ada hal lain yang mengubahnya".

Makna dari kaidah tersebut ialah hukum yang berlaku akan tetap berfungsi pada setiap kejadian dan berbagai peristiwa

${ }^{21}$ Departemen Agama RI, Al-Qur'an dan Terjemahannya, (Surabaya: Mahkota, 1971), 231. 
sampai dasar hukum baru muncul yang dapat menggantikan hukum lama tetapi tetap tidak bertentangan dengan sumber hukum yang ada. Contohnya, apabila seorang pembeli membeli barang elektronik tanpa adanya perjanjian bahwa barang tersebut dapat dikembalikan terjadi kerusakan dalam waktu tertentu atau barang tersebut tidak memiliki garansi, maka pihak pemilik toko dapat menolak karena tidak terdapat perjanjian tersebut. Bahkan apabila pembeli tersebut mengajukan gugatan tidak dapat dibenarkan karena perjanjian awal menyatakan bahwa barang tersebut tanpa garansi.

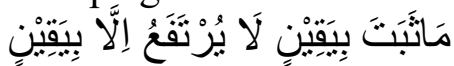

"sesuatu yang ditetapkan dengan keyakinan tidak bisa dihilangkan kecuali dengan keyakinan".

Kaidah selanjutnya ialah seseorang yang memilki keyakinan terhadap sesuatu akan tetap menjadi keyakinannya sampai keyakinannya berubah terhadap peristiwa tersebut. Contohnya, apabila dua orang yang saling berselisih memperebutkan sesuatu maka yang dianggap benar ialah seseorang yang dituduh, keyakinan tersebut akan tetap terjadi sampai bukti menunjukkan bahwa tertuduh bersalah.

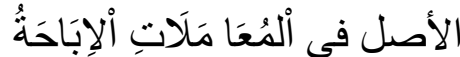

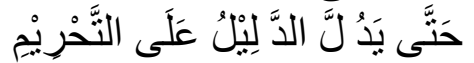

"Hukum asal semua muamalat adalah boleh, hingga ada dalil yang kebolehannya".
Sebagaimana yang telah dipaparkan dalam kaidah tersebut bahwa semua kegiatan muamalat hukumnya boleh sampai ada hukum yang merubahnya. Misalnya, hukum jual beli adalah boleh sedangkan hukum riba yaitu haram karena merugikan orang lain sebagaimnaa yang telah dijelaskan dalah surah alBaqarah ayat 275.

$$
\begin{aligned}
& \text { الأصل فحى كُلِ حَادِثٍ تَقْدِيْرُهُ }
\end{aligned}
$$

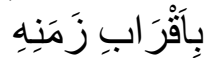

"Hukum asal setiap peristiwa penetapan hukumnya menurut masa yang terdekat dengan kejadiannya." 22

Setap kejadian telah ditetapkan hukumnya. Apabila salah satu peristiwa tidak ditemukan hukumnya dalam sumber hukum, maka diambillah sumber yang paling dekat dan berkaitan dengan kejadian tersebut yang dijadikan sebagai acuan atau tolak ukur dalam menyelesaikan peristiwa yang terjadi.

\section{Jual beli}

Jual beli secara bahasa ialah perniagaan sedangkan secara terminologi ialah menukar sesuatu dengan dasar ridha. Jual beli merupakan kegiatan tukar menukar barang dengan sesuatu, artinya menukar suatu barang yang memiliki nilai sama atau menukar barang dengan sesuatu yang memiliki nilai. Dengan kata lain jual beli

${ }^{22}$ Duski Ibrahim, al Qawa'id al Fiqhiyah (kaidah-kaidah fiqih), (Noer Fikri: Palembang, 2019), 58. 
merupakan pemindahkan kepemilikan suatu barang dengan imbalan sesuai dengan izin pemiliknya. ${ }^{23}$

\section{Dasar hukum jual beli}

Dasar membolehkannya jual beli terdapat dalam surat albaqarah ayat 275 ,

$$
\text { وَاَحَلَّ السَُّ الْلَيْعَع وَحَرَّمَ الرِّبَوَ ا }
$$

"Dan Allah menghalalkan jual beli dan mengharamkan riba (Qs. al-baqarah: 275)". ${ }^{24}$
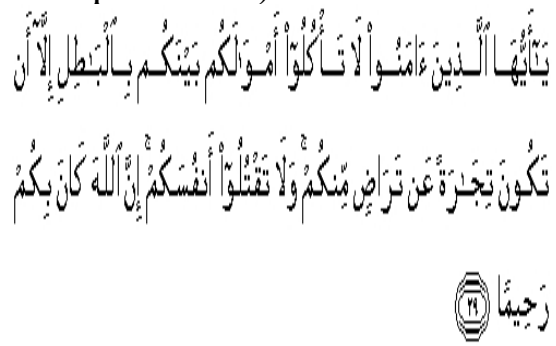

"Hai orang-orang yang beriman, janganlah kamu saling memakan harta sesamamu dengan jalan yang batil, kecuali dengan jalan perniagaan yang berlaku dengan suka sama-suka di antara kamu. Dan janganlah kamu membunuh dirimu, sesungguhnya Allah adalah Maha Penyayang kepadamu". 25

\section{Rukun dan syarat jual beli}

Beberapa rukun dan syarat terjadi jual beli antara lain:

1. Para pihak

Syaratnya para pihak yaitu suka sama suka, berakal

${ }^{23}$ Ascara, Akad dan Produk Bank Syariah: Konsep dan Praktek di beberapa Negara, (Rajagrafindo: Jakarta, 2006), 78.

${ }^{24}$ Departemen Agama RI, Al-Qur'an dan Terjemahannya, (Surabaya: Mahkota, 1971), 122.

${ }^{25}$ Ibid., 387. dan dengan kehendak sendiri atau bukan karena paksaan.

2. Obyek akad

Syaratnya suci, ada manfaat barang yang diperjual belikan dan dapat diserahkan oleh penjual dan barang tersebut merupakan milik penjual.

3. Kesepakatan kedua pihak.

Merupakan ucapan kedua pihak atau ijab dan qabul yang dilakukan oleh penjual dan pembeli secara bersambung. ${ }^{26}$

\section{Jual beli lelang}

Sistem jual beli dengan lelang di Indonesia sudah berlangsung lama. Peraturan tersebut berlaku sejak 1 april 1908 yang diatur dalam pasal 1 peraturan lelang yang menyebutkan mengenai peraturan penjualan di muka umum sebagai berikut "pelelangan dan penjualan barang yang diadakan di muka umum dengan penawaran harga yang makin meningkat dengan persetujuan harga yang semakin meningkat atau dengan pendaftaran harga atau orang-orang yang diundang atau sebelumnya sudah diberitahukan tentang pelelangan maupun penjualan."

Dalam transaksi muamalah jual beli lelang dikenal sebagai penjualan barang di muka umum dengan penawaran tertinggi. Islam memberikan kebebasan seluruh masyarakat dalam melaksanakan berbagai macam

${ }^{26}$ Sulaiman Rasid, Fiqh Islam, (Bandung: Sinar Baru, 1989). hal. 278. 
transaksi untuk mencapai ridho dan rizki Allah SWT.

\section{Sistem Lelang}

Berdasarkan teknik penawarannya pelelangan dibagi menjadi dua sistem antara lain:

1. Sistem pelelangan dengan penawaran lisan.

Sistem ini dibagi menjadi beberapa macam yakni pelelelangan dengan penawaran lisan berjenjang naik dan pelelangan dengan penawaran berjenjang turun. Pada pelelangan pertama salah satu orang yang ditunjuk sebagai juru bicara menyebutkan harga terhadap suatu barang yang akan dilelang dimulai dengan harga paling rendah dengan sistem tawar menawar dengan calon pembeli sampai harga paling tinggi. Sedangkan yang dimaksud dengan pelelangan dengan penawaran harga berjenjang turun. Salah satu juru bicara memulai penawaran dengan harga tertinggi terhadap suatu barang lelang. Apabila penawaran tersebut belum ada peminatnya maka harga akan diturunkan terus menerus sampai salah satu peminat merasa tertarik.

2. Sistem Pelelangan dengan penawaran tertulis.

Sistem ini menggunakan sebuah berkas yang diberikan kepada para calon pembeli. Hal pertama yang harus dilakukan ialah juru lelang membagikan surat penawaran yang telah disediakan oleh penjual kemudian para calon pembeli mengisi seluruh persyaratan dan harga yang diberikan oleh pembeli. Harga tertinggi akan menjadi pemilik barang yang dilelang, apabila terjadi dua harga yang sama maka akan dilakukan pengundian kepada calon pembeli sebagai pemenang lelang.

\section{Rukun dan Syarat-syarat lelang}

Rukun lelang terdiri dari:

1. Transaksi dilaksanakan oleh pihak yang cakap hukum dengan dasar suka sama suka.

2. Obyek lelang harus halal dan bermanfaat

3. Kejelasan terhadap barang lelang

4. Kesangupan menyerahkan barang dari penjual

5. Tidak menggunakan tindakan yang mengarah kepada suap atau lainnya.

6. Kejelasan mengenai harga yang telah disepakati bersama

Syarat lelang ialah:

1. Bukti dari pemohon lelang

2. Bukti kepemilikan terhadap barang

3. Keadaan fisik dari barang tersebut.

\section{Jual beli lelang perspektif istishab}

Surat al-baqarah ayat 275 mengenai jual beli dapat diistishabkan yakni Allah menghalalkan jual beli dan mengharamkan riba, hal tersebut akan tetap berlaku sampai terdapat ayat al-qur'an yang 
menjelaskan bahwa hukum jual beli dan hukum riba berubah. Pada masa sekarang hukum jual beli tetap halal bagi semua manusia dan riba tetap haram dilakukan.

Surat an-nisa ayat 29 merupakan larangan memakan harta sesama dengan jalan batil. Larangan tersebut akan tetap berlaku kepada semua orang sampai terdapat dasar hukum yang menjelaskan bahwa larangan memakan harta sesama hukumnya telah berubah. Selanjunya perniagaan dilakukan atas dasar suka sama suka. Keterkaitan antara istishab dengan surat an-nisa ialah kewajiban melaksanakan transaksi jual beli dengan dasar suka sama suka akan tetap berlaku sampai ditemukannya dasar hukum yang menjelaskan bahwa jual beli dapat dilaksanakan dengan keterpaksaan. Jual beli lelang (muzayyadah) dalam hukum Islam diperbolehkan. ${ }^{27}$ Pada dasarnya jual beli merupakan kegiatan transaksi yang dilkukan oleh setiap orang mulai dari anak-anak sampai dewasa. Transaksi jual beli terjadi sejak dahulu bahkan rasululah telah melakukan transaksi jual beli atau berdagang. Hal tersebut telah dijelaskan dalam surat albaqarah ayat 275 tentang kebolehan melaksanakan transaksi jual beli.

Islam membolehkan jual beli barang halal dengan cara

${ }^{27}$ Ana Selvia Khoerunisa, dkk, "Jual Beli Lelang Perspektif Hukum Islam”, 34. lelang atau disebut bai' muzayadah. Sebagaimana Nabi SAW bersabda:

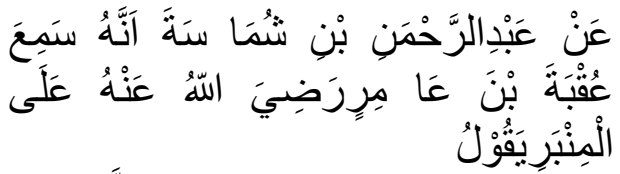

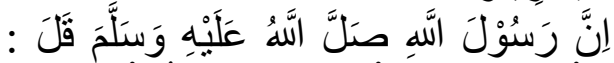

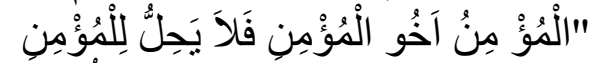

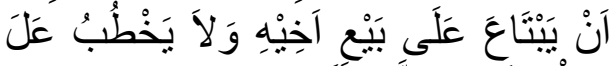

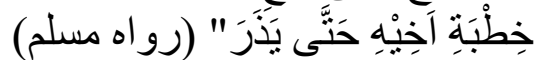
"Diriwayatkan dari 'Abdurrahman bin Syumsyah bahwa dia berkata pernah mendengar 'Uqbah bin Amir r.a. berpidato diatas minbar, dia berkata, sesungguhnya Rasulullah Saw bersabda, orang mukmin merupakan saudara mukmin lainnya, maka tidak halal bagi mereka seorang mukmin membeli barang yang sedang ditawar saudaranya dan tidak halal pula melamar yang sedang dilamar saudaranya sampai dia meninggalkannya (terlebih dahulu) (HR. Muslim)". ${ }^{28}$

Hadis tersebut dapat diistishabkan yakni dalam hadis tersebut menjelaskan larangan dalam melakukan tawar menawar barang yang sedang ditawar oleh saudaranya. Dalam jual beli lelang yang dikatakan larangan ialah apabila setelah penutupan lelang suatu barang dan barang tersebut menjadi milik orang lain dengan harga yang telah disepakati para pihak di muka selanjutnya ditawar oleh orang lain dengan harga yang lebih tinggi, maka hal tersebut

${ }^{28}$ Abi Isa Muhammad bin Isa bin Saurah At-Tirmidzi, Jami' At - Tirmidzi , (Riyadh: Al-Mutaman Tradingest, tt), 217. 
tidak diperbolehkan. Maka seseorang yang ditunjuk sebagai juru bicara jual beli lelang tidak diperbolehkan menerima tawaran yang diberikan meskipun dengan harga yang lebih tinggi.

Hadis lainnya juga meyebutkan mengenai kebolehan jual beli lelang yakni:

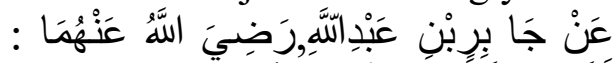

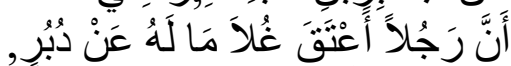

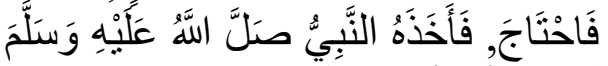

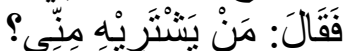

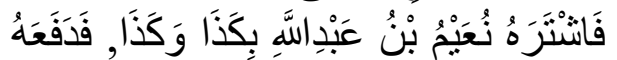

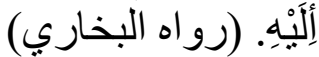

"Dari Jabir bin 'Abdullah: seorang laki-laki telah memutuskan bahwa sepennggal ia akan memerdekakan budaknya, tak lama kemudian ia membutuhkan uang, maka Nabi Saw membawa budak itu dan berkata, siapa yang akan membeli budak ini dariku? Nu'man bin Abdullah membeli dengan harga sekian dan Nabi Saw memberikan hasil dari penjualan budak tersebut kepada pemiliknya

(HR Bukhari)". ${ }^{29}$

Hadis

tersebut menjelaskan bahwa Nabi Saw telah membantu seseorang yang sedang sakit untuk memerdekakan budaknya. Beliau menawarkan budak tersebut kepada para sahabat dengan sistem tawar menawar. Berkaitan dengan hadis tersebut jual beli dengan cara lelang diperbolehkan. Kegiatan tersebut tetap berlaku pada kondisi yang

${ }^{29}$ Ibid., 297. sama sampai ditemukannya hadis lain yang merubahnya.

\section{KESIMPULAN}

Istishab merupakan menetapan hukum dengan tetap memberlakukan hukum yang ada untuk saat ini dan yang akan datang sesuai dengan hukum yang berlaku pada waktu sebelumnya.

Jual beli lelang merupakan kegiatan tawar menawar dalam penjualan yang diwakilkan oleh seseorang sebagai juru bicara dalam penjualan produk. Kegiatan ini dilakukan oleh pihak-pihak tertentu atau orang yang mendapatkan undangan pelelangan sehingga barang yang akan dileleng memilki nominal atau harga yang tinggi.

Jual beli lelang dianggap sah dilakukan para pihak selama memenuhi rukun dan syarat jual beli lelang, tetapi kegiatan tersebut dianggap tidak sah apabila transaksi tersebut tidak memenuhi rukun dan syara'. Berdasarkan kaidah istishab jual beli lelang hukumnya boleh.

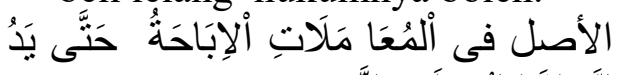

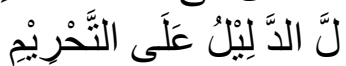

Kaidah tersebut memiliki arti bahwa asal dari hukum muamalah ialah boleh sampai ada dalil yang merubahnya. Jual beli lelang diperbolehkan selama saling menguntungkan para pihak. Jual beli lelang tetap halal dilakukan dalam situasi dan kondisi apapun sampai ditemukannya hukum baru yang dapat merubah hukum lama dengan tetap bersandar kepada nash 


\section{REFERENSI}

[1] al-Asnawy, Abd al-Rahim ibn Hasan al-Syafi'i,. t.t., Nihayah al-Saul fi Syarh Minhaj al-Ushul, Al-Mathba'ah al-Salafiyah., Kairo.

[2] al-Syaukany, Muhammad ibn Ali., Irsyad al-Fuhul ila Tahqiq al-Haq min 'Ilm al-Ushul, Dar al-Kutub al-'Ilmiyyah., Beirut.

[3] Ascara., 2006, Akad dan Produk Bank Syariah: Konsep dan Praktek di beberapa Negara, Rajagrafindo., Jakarta.

[4] At-Tirmidzi, Abi Isa Muhammad bin Isa bin Saurah., tt, Jami' At Tirmidzi, Al-Mutaman Tradingest., Riyadh.

[5] Darmawan., 2020, Ushul Fiqh, revka prima media anggata IKAPI.

[6] Departemen Agama RI., 1971, Al-Qur'an dan Terjemahannya, Mahkota., Surabaya.

[7] Haq, Husnul., 2017, Penggunaan Istishab dan pengaruhnya terhadap perbedaan ulama, ALHURRIYAH : Jurnal Hukum Islam, Vol. 02 , No. 01.

[8] Ibrahim, Duski., 2019, al Qawa 'id al Fiqhiyah (kaidah-kaidah fiqih), Noer Fikri., Palembang.

[9] Kartono, Kartini., 1998, Pengantar Metodologi Research, Bandung., ALUMNI.

[10] Khoerunisa, Ana Selvia, dkk., 1989, Jual Beli Lelang Perspektif Hukum Islam...

[11] Moleong, Lexy J., 2002, Metodologi Penelitian Kualitatif, PT. Remaja Rosdakarya., Bandung.

[12] Rasid Sulaiman., 1989, Fiqh Islam, Sinar Baru., Bandung.

[13] Ridwan., 2011, Istishab dan penerapannya dalam hukum Islam, almanahij, Vol.v No. 1.

[14] Shalihah, Siti., 2018, istishab (sebuah teori dan praktik prinsip-prinsip nahwu arab), al-ittijah, Vol. 10 No. 02.

[15] Surachman, Winarno., 1990, Pengantar Penelitian Ilmiah: Dasar, Metode, Teknik., Tarsita., Bandung.

[16] Syafe'I, Rahmad., 2007, Ilmu Ushul Fiqh, Pusaka Setia., Bandung.

[17] Zed, Mustika., 2004, Metode Penelitian Kepustakaan, Yayasan Obor Nasional., Jakarta. 